\title{
PENGARUH PENYULUHAN MEDIA AUDIO VISUAL VIDEO TERHADAP PERILAKU CUCI TANGAN PAKAI SABUN PADA SISWA KELAS III DI SDN 027 SAMARINDA
}

\author{
Herni Johan1), Dian Puspita Reni2), Siti Noorbaya3) \\ 1), 2), 3) Akademi Kebidanan Mutiara Mahakam Samarinda \\ E-mail: hernijohan@akbidmm.ac.id
}

\begin{abstract}
Handwashing behavior is an activity, a hand washing action performed by an individual that can be observed directly or indirectly. Health behavior problems in school-aged children are usually associated with personal hygiene and the environment, one of which is the habit of washing hands with soap. Wrong handwashing techniques can cause diarrhea and ARI in children. The purpose of this study was to determine the effect of audio visual video counseling on the behavior of handwashing with soap in students SDN 027 Samarinda. The research design used quasi experiment (Quasy experiment) with one group pretest-posttest design. Total samples were 56 respondents, with total of 28 respondents and control group 28 respondents. The instrument used is a checklist. Prior to data analysis, the data normality test was performed with Shapiro-Wilk. Test used mann whitney and wilcoxon signed ranks test. The result of statistical test with Mann Whitney Test showed that in pre test of control and experiment test was $0,083>0,05$, post control test and experiment test were 0,001<0,05. The results of pretest and posttest statistical test group experiments with Wilcoxon Signed Ranks Test showed that the value of $0.001<0.05$ (there is a significant difference). Meanwhile, in the control group with Wilcoxon Signed Ranks Test showed that the value of $0.173>0.05$ (no significant difference). For media education practitioners this can be an alternative in teaching handwashing with soap and is expected to improve handwashing behavior with soap not only in school but applied in everyday life.
\end{abstract}

Key words : Audio visual, Washing hand, Diarrhea

\begin{abstract}
ABSTRAK
Perilaku mencuci tangan adalah suatu aktivitas, tindakan mencuci tangan yang di kerjakan oleh individu yang dapat diamati secara langsung maupun tidak langsung. Permasalahan perilaku kesehatan pada anak usia sekolah biasanya berkaitan dengan kebersihan perorangan dan lingkungan, salah satunya adalah kebiasaan mencuci tangan pakai sabun. Teknik cuci tangan yang salah dapat menyebabkan diare dan ISPA pada anak. Tujuan penelitian ini adalah untuk mengetahui pengaruh penyuluhan media audio visual video terhadap perilaku cuci tangan pakai sabun pada siswa SDN 027 Samarinda.

Desain penelitian menggunakan eksperimen semu (Quasy eksperimen) dengan rancangan one group pretest-posttest. Total sampel 56 responden, dengan jumlah kelompok eksperimen sebanyak 28 responden dan kelompok kontrol sebanyak 28 responden. Instrumen yang digunakan adalah checklist. Sebelum dilakukan analisa
\end{abstract}


data, dilakukan uji normalitas data dengan Shapiro-Wilk. Uji yang digunakan mann whitney dan wilcoxon signed ranks test.

Hasil uji statistik dengan Mann Whitney Test menunjukkan bahwa pada uji pre test kontrol dan eksperimen sebesar 0,083 > 0,05, uji post test kontrol dan eksperimen sebesar 0,001 < 0,05. Hasil uji statistik pretest dan posttest kelompok eksperimen dengan Wilcoxon Signed Ranks Test menunjukkan bahwa nilai 0,001 < 0,05 (ada perbedaan yang bermakna). Sedangkan, pada kelompok kontrol dengan Wilcoxon Signed Ranks Test menunjukkan bahwa nilai 0,173 >0,05 (tidak ada perbedaan yang bermakna).

Bagi praktisi pendidikan media ini dapat menjadi alternatif dalam mengajarkan perilaku cuci tangan pakai sabun dan diharapkan dapat meningkatkan perilaku cuci tangan pakai sabun tidak hanya di sekolah tetapi diterapkan dalam kehidupan sehari-hari.

Kata kunci: Audio visual, Cuci Tangan, Diare

\section{PENDAHULUAN}

Indonesia merupakan salah satu negara dengan jumlah penduduk yang padat. Jumlah penduduk Indonesia berdasarakan data BPS (2010) berjumlah 237,6 juta jiwa dengan laju pertumbuhan penduduk sebesar $1,49 \%$ per tahun. Jumlah anak-anak di Indonesia sekitar 28\%$34 \%$ dari keseluruhan jumlah penduduk Indonesia. Jumlah penduduk sebanyak itu akan menimbulkan tantangan dan permasalahan tersendiri di bidang kesehatan. Indikator yang digunakan dalam derajat kesehatan terutama kesehatan anak di Indonesia yaitu angka kematian, angka kesakitan, status gizi dan harapan hidup waktu lahir [1].

Anak merupakan aset terpenting di suatu negara, karena merupakan generasi penerus bangsa selanjutnya. Derajat kesehatan anak pada saat ini belum bisa dikatakan baik karena masih terdapat banyak masalah kesehatan khususnya pada anak sekolah. Anak usia sekolah merupakan kelompok usia yang rentan terhadap masalah kesehatan dan rentan terhadap perubahan. Masalah ini kurang begitu diperhatikan baik dari orang tua, sekolah, para klinisi atau profesional kesehatan lainnya yang saat ini masih memprioritaskan kesehatan anak balita. Padahal peranan mereka yang sangat dominan akan mempengaruhi kualitas hidup anak dikemudian hari [2].

Usia sekolah adalah anak usia 612 tahun. Usia sekolah merupakan masa anak memperoleh dasar-dasar pengetahuan untuk keberhasilan penyesuaian diri pada kehidupan dewasa dan memperoleh keterampilan tertentu [2].

Anak usia sekolah dibagi menjadi 2 periode yaitu masa anak tengah (middle Childhood) pada masa ini anak-anak kira-kira berumur 7-9 tahun. Masa anak akhir (late childhood) anak dengan usia 10-12 tahun. Pada fase ini anak-anak terus mengembangkan kapasitas intelektual (masa operasi konkrit) di bangku pendidikan formal yaitu sekolah dasar. 
Perilaku mencuci tangan adalah suatu aktivitas, tindakan mencuci tangan yang di kerjakan oleh individu yang dapat diamati secara langsung maupun tidak langsung. Kesehatan seseorang dipengaruhi oleh dua faktor pokok yaitu faktor perilaku (behavior causes), dan faktor non perilaku (non behavior causes). Faktor-faktor yang mempengaruhi perilaku kesehatan khususnya perkembangan anak diantaranya kesehatan, budaya, agama dan kebiasaan setempat serta perlakuan orang tua dalam mendidik anak.

Permasalahan perilaku kesehatan pada anak usia sekolah biasanya berkaitan dengan kebersihan perorangan dan lingkungan, salah satunya adalah kebiasaan mencuci tangan pakai sabun. Hal yang mengindikasikan bahwa perilaku cuci tangan pakai sabun yang merupakan suatu upaya yang mudah, sederhana, murah, dan berdampak besar bagi pencegahan penyakit-penyakit menular seperti diare dan ISPA belum menjadi kebiasaan pada anak usia sekolah padahal anak diusia tersebut rentan terhadap penyakit seperti diare dan ISPA [2][7].

Tujuan penelitian ini adalah untuk mengetahui pengaruh penyuluhan media audio visual video terhadap perilaku cuci tangan pakai sabun pada siswa SDN 027 Samarinda.

\section{METODE}

Desain penelitian menggunakan eksperimen semu (Quasy eksperimen) dengan rancangan one group pretest-posttest. Rancangan ini ada kelompok pembanding.
Populasi pada penelitian ini adalah seluruh siswa SD kelas 3 di SD N 027 Samarinda yang berjumlah 65 anak. Sampel yang digunakan ini berjumlah 56 responden, dengan masing-masing kelompok berjumlah 28 responden. Sehingga kelompok eksperimen berjumlah 28 responden dan kelompok kontrol berjumlah 28 responden. Kriterian inklusi sampel dalam penelitian ini yaitu siswa SD N 027 Samarinda kelas 3 , bersedia menjadi responden. Sedangkan kriteria eksklusi sampel dalam penelitian ini yaitu siswa yang tidak hadir pada saat penelitian, dalam keadaan sakit.

Instrumen yang digunakan untuk mengukur mengukur perilaku cuci tangan pakai sabun adalah checklist. Checkist yang digunakan adalah cuci tangan 6 langkah yang sudah tersetandar. Penentuan skor untuk checklist cuci tangan pakai sabun menggunakan skor 0 jika jawaban tidak dan skor 1 jika jawaban ya.

Hipotesa dalam penelitian ini adalah "Ada pengaruh penyuluhan media audio visual video terhadap perilaku cuci tangan pakai sabun pada siswa SD kelas 3 di SDN 027 Samarinda".

Variabel-variabel dalam penelitian ini menggunakan skala ukur nominal dan ordinal. Analisis data yang digunakan non parametrik. Sebelum dilakukan analisa data, terlebih dahulu akan dilakukan uji normalitas data dengan menggunakan Shapiro-Wilk. Setelah diketahui bahwa data berdistribusi tidak normal, selanjutnya dilakukan analisis data dengan menggunakan uji no parametrik. Uji parametrik yang 
digunakan mann whitney dan

wilcoxon signed ranks test.

HASIL

Tabel 1

Karakteristik Subyek

Berdasarkan Usia

\begin{tabular}{ccccc}
\hline Usia & \multicolumn{2}{c}{ Kontrol } & \multicolumn{2}{c}{ Eksperimen } \\
(Tahun) & (f) & (\%) & (f) & (\%) \\
\hline 8 & 2 & 7.2 & 1 & 3.6 \\
9 & 24 & 85.6 & 24 & 85.6 \\
10 & 2 & 7.2 & 3 & 10.8 \\
Jumlah & 28 & 100 & 28 & 100 \\
\hline
\end{tabular}

Berdasarkan table diatas jumlah terbanyak kategori usia anak kelas 3 di SDN 027 Samarinda pada kelompok kontrol yaitu usia 9 tahun, sebanyak 24 responden (85,6\%). Pada kelompok eksperimen jumlah terbanyak kategori usia anak kelas 3 di SDN 027 Samarinda yaitu usia 9 tahun, sebanyak 24 responden $(85,6 \%)$.

Tabel 2

Karakteristik Subyek Berdasarkan Jenis Kelamin

\begin{tabular}{ccccc}
\hline \multirow{2}{*}{$\begin{array}{c}\text { Jenis } \\
\text { Kelamin }\end{array}$} & \multicolumn{2}{c}{$\begin{array}{r}\text { Kontrol } \\
\text { (\%) }\end{array}$} & $\begin{array}{c}\text { Eksperimen } \\
\text { (f) }\end{array}$ & (\%) \\
\hline Laki-laki & 10 & 35.7 & 7 & 25 \\
Perempuan & 18 & 64.3 & 11 & 75 \\
Jumlah & 28 & 100 & 28 & 100 \\
\hline
\end{tabular}

Dari tabel 2 jumlah kategori jenis kelamin anak terbanyak pada kelompok kontrol yaitu anak dengan jenis kelamin perempuan sebanyak 18 responden (64,3\%). Pada kelompok eksperimen jumlah kategori jenis kelamin terbanyak yaitu anak dengan jenis kelamin perempuan, sebanyak 11 subyek (75\%).
Tabel 3

Kriteria Perilaku Cuci Tangan Pakai Sabun Kelompok Kontrol

\begin{tabular}{ccc}
\hline & N & $\%$ \\
\hline Pre test & & \\
Kurang & 27 & 98.2 \\
Baik & 1 & 1.8 \\
Post test & & \\
Kurang & 23 & 82.1 \\
Baik & 5 & 17.9 \\
\hline Interpretasi & data & diatas
\end{tabular}

menunjukkan bahwa pada saat pretest kelompok kontrol perilaku cuci tangan siswa dengan kategori kurang sebanyak 27 responden $(98,2 \%)$ dan kategori baik sebanyak 1 responden $(1,8 \%)$. Sedangkan, setelah perlakuan (posttest) kelompok kontrol perilaku cuci tangan siswa dengan kategori kurang sebanyak 23 responden $(82,1 \%)$ dan kategori baik sebanyak 5 responden (17,9\%).

Tabel 4

Hasil Analisis Kriteria Perilaku Cuci Tangan Pakai Sabun Kelompok Eksperimen

\begin{tabular}{ccc}
\hline & N & $\%$ \\
\hline Pre test & & \\
Kurang & 27 & 98.2 \\
Baik & 1 & 1.8 \\
$\begin{array}{c}\text { Post test } \\
\text { Kurang }\end{array}$ & 6 & 21.4 \\
Baik & 22 & 78.6 \\
\hline Interpretasi & data & diatas
\end{tabular}

menunjukkan bahwa pada saat pretest kelompok eksperimen perilaku cuci tangan siswa dengan kategori kurang sebanyak 27 responden $(98,2 \%)$ dan kategori baik sebanyak 1 responden (1,8\%). Sedangkan, 
setelah perlakuan (posttest) kelompok eksperimen perilaku cuci tangan siswa dengan kategori kurang sebanyak 6 responden $(21,4 \%)$ dan kategori baik sebanyak 22 responden $(78,6 \%)$.

Tabel 5

Hasil Uji Normalitas Data (Eksperimen)

\begin{tabular}{ccc}
\hline Domain & Nilai $\mathbf{P}$ & Hasil \\
\hline Pre test & 0,000 & Tidak normal \\
Post Test & 0,000 & Tidak normal \\
\hline
\end{tabular}

Tabel 6

Hasil Uji Normalitas Data (Kontrol)

\begin{tabular}{ccc}
\hline Domain & Nilai $\mathbf{P}$ & Hasil \\
\hline Pre test & 0,000 & Tidak normal \\
Post Test & 0,000 & Tidak normal \\
\hline
\end{tabular}

Tabel 7

Hasil Uji Pretest Kontrol $><$ Pretest Eksperimen dengan Mann Whitney

Pretest-

Posttest

Asymp. Sig. (2- $\quad 0,083$ tailed)

Tabel 8

Hasil Uji Posttest Kontrol $><$ Posttest Eksperimen dengan Mann Whitney

\begin{tabular}{cc}
\hline & $\begin{array}{c}\text { Pretest- } \\
\text { Posttest }\end{array}$ \\
\hline $\begin{array}{c}\text { Asymp. Sig. (2- } \\
\text { tailed) }\end{array}$ & 0,001 \\
\hline
\end{tabular}

Dari Tabel 5 dan tabel 6 Hasil uji normalitas data dari masing-masing kelompok menunjukkan bahwa masing-masing kelompok memiliki hasil nilai $P<0,05$ dan lebih kecil dari nilai $P$ (signifikansi) $>0,05$. Sehingga, dari hasil tersebut dapat disimpulkan bahwa data berdistribusi tidak normal.
Dari Hasil uji statistik dengan Mann Whitney Test menunjukkan bahwa pada uji pre test didapatkan nilai $0,083>0,05$, sedangkan pada uji post test didapatkan nilai 0,001 < 0,05 , dari hasil tersebut berarti ada perbedaan yang bermakna secara statistik, antara kelompok eksperimen dan kelompok kontrol dalam uji post test. Hal dapat disimpulkan ada pengaruh penyuluhan media audio visual video terhadap perilaku cuci tangan pakai sabun pada siswa SD kelas 3 di SDN 027 Samarinda.

Tabel 9

Hasil Analisis Menggunakan Wilcoxon Signed Ranks Test Kelompok Eksperimen

\begin{tabular}{cc}
\hline & $\begin{array}{c}\text { Pretest- } \\
\text { Posttest }\end{array}$ \\
\hline $\begin{array}{c}\text { Asymp. Sig. (2- } \\
\text { tailed) }\end{array}$ & 0,000 \\
\hline
\end{tabular}

Dari tabel diatas hasil uji statistik dengan Wilcoxon Signed Ranks Test menunjukkan bahwa nilai 0,000 < 0,05 . Berarti ada perbedaan yang bermakna secara statistik, antara pretest dan posttest pemberian penyuluhan media audio visual video terhadap perilaku cuci tangan pakai sabun pada kelompok eksperimen pada siswa SD kelas 3 di SDN 027 Samarinda, dalm bentuk post test.

Tabel 10

Hasil Analisis Menggunakan

Wilcoxon Signed Ranks Test

Kelompok Kontrol

Pretest-

Posttest

Asymp. Sig. (2- $\quad 0,173$ tailed) 
Dari tabel 10 hasil uji statistik dengan Wilcoxon Signed Ranks Test menunjukkan bahwa nilai $0,173>$ 0,05 . Berarti tidak ada perbedaan yang bermakna secara statistik, antara pretest dan postest pemberian penyuluhan media audio visual video terhadap perilaku cuci tangan pakai sabun pada kelompok kontrol pada siswa SD kelas 3 di SDN 027 Samarinda.

\section{PEMBAHASAN}

Interpretasi data pada tabel 3 menunjukkan bahwa pada saat pretest kelompok kontrol perilaku cuci tangan siswa dengan kategori kurang sebanyak 27 responden $(98,2 \%)$ dan kategori baik sebanyak 1 responden $(1,8 \%)$. Sedangkan, setelah perlakuan (posttest) kelompok kontrol perilaku cuci tangan siswa dengan kategori kurang sebanyak 23 responden $(82,1 \%)$ dan kategori baik sebanyak 5 responden (17,9\%). Sedangkan, data pada tabel 4 menunjukkan bahwa pada saat pretest kelompok eksperimen perilaku cuci tangan siswa dengan kategori kurang sebanyak 27 responden $(98,2 \%)$ dan kategori baik sebanyak 1 responden (1,8\%). Sedangkan, setelah perlakuan (posttest) kelompok eksperimen perilaku cuci tangan siswa dengan kategori kurang sebanyak 6 responden $(21,4 \%)$ dan kategori baik sebanyak 22 responden (78,6\%). Pada kelompok eksperimen mengalami peningkatan pada kategori perilaku cuci tangan "baik". Proporsi tersebut menunjukkan bahwa perilaku cuci tangan pakai sabun yang diberi penyuluhan media audio visual video cenderung mengalami peningkatan perilaku cuci tangan pakai sabun dengan baik dibandingkan dengan kelompok yang tidak diberi penyuluhan media audio visual video.

Proporsi tersebut menunjukkan bahwa perilaku cuci tangan pakai sabun yang diberi penyuluhan media audio visual video cenderung mengalami peningkatan perilaku cuci tangan pakai sabun dengan baik dibandingkan dengan kelompok yang tidak diberi penyuluhan media audio visual video.

Penyuluhan dengan media audio visual video dapat meningkatkan perilaku. Hal ini sependapat dengan pendekatan Green bahwa dengan pendekatan edukasional dapat merubah perilaku seseorang termasuk pengetahuan, dimana intervensi yang diberikan merupakan proses pendidikan kesehatan untuk merubah perilaku [3].

Setelah seseorang mengetahui objek atau stimulus, proses selanjutnya adalah bersikap dan berperilaku terhadap stimulus atau objek tersebut ${ }^{[4]}$. Dalam penelitian ini, penyuluhan dengan media audio visual video merupakan stimulus atau objek yang diharapkan dapat memberi pengaruh pada responden untuk berperilaku sesuai dengan pesan atau isi dari tampilan video. Kelebihan media audio visual video yaitu mempermudah orang menyampaikan dan menerima informasi, mendorong keinginan orang untuk mengetahui lebih banyak informasi dari yang ditayangkan, dan dapat mengenalkan pengertian yang diperolah [3]. 
Hal ini juga sejalan dengan penelitian yang dilakukan oleh Danuwirahadi (2010) tentang efektifitas metode expository teaching terhadap perilaku cuci tangan dengan menggunakan sabun yang menyebutkan bahwa metode expository teaching memberikan pengaruh dalam meningkatkan perilaku cuci tangan dengan menggunakan sabun pada siswa SD kelas 1 [5]. Efektifitas penyuluhan kesehatan oleh peer group dan tenaga kesehatan tentang perilaku hidup bersih sehat (PHBS) cuci tangan bersih pada siswa SD $\mathrm{N} 01$ dan SD N 02 Bonosari Sempor Kebumen yang menyatakan tidak ada beda yang signifikasi antara penyuluhan peer group dengan penyuluhan oleh petugas kesehatan terhadap tingkat pengetahuan tentang cuci tangan bersih di SD N 01 dan SDN 02 Bonosari, Sempor, Kebumen. Hal ini menyatakan bahwa pemberian penyuluhan yang diberikan oleh peer group dan tenaga kesehatan sama-sama bisa meningkatkan pengetahuan perilaku hidup bersih sehat (PHBS) cuci tangan bersih nampun dari keduanya tidak ada yang lebih efektif sesui dengan hasil penelitian.

Pengaruh pemberian pendidikan kesehatan mencuci tangan pakai sabun menggunakan media film terhadap perubahan perilaku mencuci tangan pakai sabun pada anak usia sekolah terbukti bahwa penyuluhan dengan media film berpengaruh secara signifikan terhadap peningkatan perilaku mencuci tangan pakai sabun pada anak usia sekolah [6].
Hal ini sesuai dengan pengaruh pemberian penyuluhan media audio visual video. Perilaku yang didasari oleh pengetahuan akan lebih langgeng dari pada perilaku yang tidak didasari oleh pengetahuan. pabila penerimaan perilaku baru atau adopsi perilaku di dasari oleh pengetahuan, pemahaman, kesadaran, dan sikap positif, maka perilaku tersebut akan bersifat lenggeng (longlasting). Sebaliknya apabila perilaku tidak didasari oleh pengetahuan, pemahaman dan kesadaran maka tidak akan berlangsung lama. Seperti, anak-anak di himbau untuk mencuci tangan oleh gurunya tanpa mengetahui makna dan tujuan mencuci tangan pakai sabun, maka sebagian besar dari anak akan lebih banyak menyepelekan kegiatan mencuci tangan tersebut walaupun telah mendapatkan himbauan mencuci tangan pakai sabun [7].

Perilaku cuci tangan pakai sabun dipengaruhi oleh beberapa faktor bahwa faktor yang mempengaruhi perilaku cuci tangan pakai sabun diantaranya umur, pendidikan, sumber informasi, dan pengetahuan. Dalam penelitian ini, anak yang memiliki usia lebih dewasa memiliki hasil perilaku cuci tangan pakai sabun lebih baik dibandingkan anak yang berusia lebih muda.

Hal ini dapat disebabkan pada anak dengan tingkat usia lebih dewasa cenderung memiliki tingkat perkembangan kognitif yang lebih baik, sehingga mampu mempersepsikan perilaku cuci tangan pakai sabun dengan benar. Umur merupakan salah satu sifat 
karakteristik tentang orang yang sangat utama, umur mempunyai hubungan dengan tingkat keterpaparan, besarnya resiko serta sikap resistensi. Perbedaan pengalaman terhadap masalah kesehatan/ penyakit dan pengambilan keputusan dipengaruhi oleh umur individu tersebut. Hasil penelitian ini menyebutkan bahwa umur mempengaruhi perilaku cuci tangan pakai sabun pada anak siswa SD kelas 3.

\section{SIMPULAN}

1. Data pada kelompok komtrol menunjukkan bahwa pada saat pretest perilaku cuci tangan siswa dengan kategori kurang sebanyak 27 responden $(98,2 \%)$ dan kategori baik sebanyak 1 responden (1,8\%). Sedangkan, setelah perlakuan (posttest) perilaku cuci tangan siswa dengan kategori kurang sebanyak 23 responden $(82,1 \%)$ dan kategori baik sebanyak 5 responden (17,9\%).

2. Data pada kelompok eksperimen menunjukkan bahwa pada saat pretest kelompok eksperimen perilaku cuci tangan siswa dengan kategori kurang sebanyak 27 responden $(98,2 \%)$ dan kategori baik sebanyak 1 responden $(1,8 \%)$. Sedangkan, setelah perlakuan (posttest) perilaku cuci tangan siswa dengan kategori kurang sebanyak 6 responden $(21,4 \%)$ dan kategori baik sebanyak 22 responden (78,6\%).

3. Hasil uji statistik pretest dan posttest kelompok eksperimen dengan Wilcoxon Signed Ranks
Test menunjukkan bahwa nilai $0,001<0,05$

4. Hasil uji statistik pretest dan posttest kelompok kontrol dengan Wilcoxon Signed Ranks Test menunjukkan bahwa nilai $0,173>$ 0,05 .

\section{SARAN}

Bagi praktisi pendidikan media audio visual video dapat menjadi alternatif dalam mengajarkan perilaku cuci tangan pakai sabun, bagi subyek penelitian agar siswa kelas 3 SDN 027 Samarinda diharapkan dapat meningkatkan perilaku cuci tangan pakai sabun tidak hanya di sekolah tetapi diterapkan dalam kehidupan sehari-hari, dan untuk peneliti selanjutnya dapat melakukan penelitian yang berkaitan tentang perilaku cuci tangan pakai sabun dan ingin mengetahui lebih dalam maka dilakukan follow up dengan jangka waktu yang lebih lama lagi.

\section{DAFTAR PUSTAKA}

[1] Hidayat, A.A, Pengantar IImu Keperawatan Anak edisi 1, Jakarta: Salemba Medika, 2006.

[2] Hendra, Permasalahan Umum Kesehatan Anak Usia Sekolah, Jakarta: Rineka Cipta, 2007.

[3] Sulaeman. A, Muchdie. dkk, Difusi Teknologi Teori, Pendekatan, dan Pengalaman, Jakarta: Pusat Pengkajian Difusi Teknogi BPPT, 2005.Notoatmodjo, IImu Perilaku Kesehatan, Jakarta : Rineka Cipta, 2010.

[4] Danuwirahardi. P, Efektifitas Motode Expository Teaching Terhadap Perilaku Mencuci Tangan dengan Menggunakan 
Sabun, Universitas Katolik

Soegijapranata Semarang, 2010).

[5] Sariasih, Pengaruh Pemberian

Pendidikan Kesehatan Mencuci

Tangan Pakai Sabun

Menggunakan Media Film

Terhadap Perubahan Perilaku

Mencuci Tangan Pakai Sabun

Pada Anak Usia Sekolah. Tugas

Akhir, Universitas Aisyah, 2011.

[6] Notoatmodjo, Promosi Kesehatan dan IImu Perilaku Kesehatan, Jakarta: Rineka Citra Intaran, 2007.

[7] Katowa P, C.M. Ngoma, M. Maimbolwa, Compliance with Infection Prevention Guidelines by Health Care Workers at Ronald Ross General Hospital Mufulir District, Medical Journal of Zambia, 2007. 